DOI: https://doi.org/10.24144/2409-6857.2020.1(55).27-35

УДК 338.43: 631.1

Куліш Л.П.

\title{
ІНСТИТУЦІЙНІ ЗАСАДИ РОЗВИТКУ КОНКУРЕНТОСПРОМОЖНОГО ОРГАНІЧНОГО ВИРОБНИЦТВА
}

\begin{abstract}
Проаналізовано основні теоретичні підходи до аналізу процесів формування інституційного середовища розвитку конкурентоспроможного органічного виробництва. Розглянуто інституційні проблеми, щзо перешкоджають ефективному господарюванню на основі органічного виробництва. Запропоновано низку заходів, реалізація яких сприятиме активізації процесів розвитку конкурентоспроможного органічного виробництва в Україні.
\end{abstract}

Ключові слова: інституційні засади, органічне виробництво, держана політика, конкурентоспроможність.

Постановка проблеми. Утвердження необхідності господарювання, що грунтується на концептуальних засадах збалансованого та стійкого довгострокового розвитку, максимальному забезпеченні гармонійних взаємин 3 природою перетворилося на стійкий економічний тренд на початку XX - наприкінці XXI ст. Про неабияку актуальність екологоекономічних проблем свідчить і багаторічні дискусії на платформі Всесвітнього економічного форуму у Давосі. Протягом останніх років проблеми захисту довкілля, раціонального використання енергетичних ресурсів, зростання частки відновлювальних джерел енергії, поступове обмеження та у перспективі - повна заборона на використання вуглеводнів, популяризація раціонального споживання, зменшення обсягу твердих побутових відходів, що продукується домашніми господарствами, та цілий ряд інших питань поступово формують вектор подальшого суспільного розвитку в умовах викликів та загроз, дія яких щоразу посилюється [1]. У цьому контексті активний розвиток органічного сільського господарства стає одним з найбільш дієвих напрямів розвитку не лише аграрної сфери, але й суспільного виробництва загалом.

Аналіз останніх досліджень та публікацій. Широкий спектр інституційних засад формування i розвитку органічного сільськогосподарського виробництва викликає значний дослідницький інтерес. Вказане коло питань проаналізовано у працях таких українських та зарубіжних вчених. Українські вчені М. Хвесик, І. Бистряков і Д. Кли-

ФКуліш Л. П., аспірантка кафедри економічної теорії та конкурентної політики Київського національного торговельно-економічного університету, e-mail: alfapanna@ukr.net, ORCID ID: https://orcid.org/0000-0003-4600-0711 новий, аналізуючи гострі соціально-економічні проблеми сучасності, зазначають, що «головним завданням для України в частині забезпечення сталого розвитку сьогодні є оновлення базових ідей та концептів досягнення поставлених цільових орієнтирів - екологічного, економічного, соціального та управлінського» $[2$, c. 4]. Логічно розвиває цей підхід В. Лагутін, вказуючи, що «особливу увагу при цьому слід приділити тим методологічним підходам, які дають змогу зрозуміти глибинні причини генезису всесвітніх економічних процесів та явищ» $[3$, с. 6$]$.

P. Безус глибоко аналізує проблеми формування інституційного середовища як одного із системних факторів розвитку органічного виробництва. Досліддник на основі ураховання специфіки сільського господарства усі інститути, що визначають розвиток виробництва органічної продукції, об'єднанує у ряд груп. При цьому місія інститутів трактується у контексті забезпечення розбудови дієвих суспільно-економічних відносин, що обумовлюють поширення органічного виробництва. Важливе значення при цьому належить регуляторній діяльності із залученням ринкового і державного інструментарію [4]. Ю. Завадська на основі проведеного аналізу доходить висновку про те, що потреба збалансованого розвитку агроекосистеми обумовила становлення i розвиток сфери органічного виробництва у багатьох країнах світу [5]. Н. Патика глибоко аналізуе напрями забезпечення конкурентоспроможності сільського господарства на основі реалізації принципів чесної конкуренції у контексті сталого розвитку аграрного сектору економіки [6].

Аналізують низку чинників формування споживчого попиту на органічну продукцію, вказуючи на ментально-культурні відмінності, що притаманні різним країнам світу, Б. Зегебарт, 
С. Беренс, К. Кларман та Н. Хеннігс [7]. Ю. Кирилов, В. Грановська та В. Крикунова глибоко досліджують фактори та напрями стимулювання розвитку органічного сегмента аграрного сектору у країнах світу [8]. Українські дослідники I. Кириленко та $€$. Милованов вказують, що «Україна на нинішньому етапі розвитку дедалі більше потребує генерації науково-прикладних досліджень і розробок для виходу на якісно новий рівень вітчизняного органічного агровиробництва» [9]. Водночас проблематика інституційного підгрунтя становлення та розвитку ринку органічної продукції потребують подальших наукових досліджень та глибокого аналізу.

Формулювання цілей статті. Метою дослідження $\epsilon$ розкриття теоретичних засад та узагальнення практичних аспектів формування інституційних засад органічного сільського господарства, а також визначення напрямів активізації розвитку органічного виробництва в Україні.

Матеріали та методи. У процесі дослідження використано загальнонаукові та спеціальні методи, такі як: історико-логічний - при розгляді еволюції органічного виробництва; системний підхід - при дослідженні теоретичних аспектів інституційного забезпечення національного органічного сектору; метод ретроспективного та порівняльного аналізу - при розгляді впливу державної політики на конкурентоспроможність національних суб'єктів ринку; аналіз та синтез при визначенні взаємозв'язків між державним та ринковим регулюванням аграрного сектору.

Опис основного матеріалу дослідження. Проведений аналіз дає змогу дійти висновку про те, що технологічні аспекти ведення органічного виробництва сприяють відновленню природної родючості грунтів, підвищенню якості сільськогосподарських угідь, зменшенню обсягів шкідливих викидів, скороченню застосування засобів хімізації та витрат невідновлюваних енергетичних ресурсів, забезпечуючи при цьому позитивний вплив на довкілля. У сучасних умовах ринок органічних продуктів харчування може стати одним з перспективних напрямів розвитку сільського господарства і споживчого ринку в Україні. Значне скорочення застосування засобів хімізації через економічні проблеми відбилося на екологічній ситуації сільськогосподарського виробництва. Це дає можливість українському сільському господарству скоротити перехідний період до органічного виробництва (період конверсії) і зажадає менше часу - переважно до трьох років, тоді як в європейських країнах цей період триває близько п’яти-семи років [10].
На підставі проведеного аналізу чинників сталого розвитку органічного виробництва виявлено процеси i визначено їхній взаємозв' язок, що забезпечує одночасно екологічну $\mathrm{i}$ продовольчу безпеку за допомогою екологізації виробництва, серед яких:

- упровадження адаптивно-ландшафтних систем землеробства, що дають змогу раціонально використовувати природні ресурси i стимулювати виробництво на основі сировини національного походження;

- започаткування підприємствами органічного виробництва 3 метою одержання безпечної і цінної фізіологічному сенсі продукції високої якості;

- формування продовольчого ринку на основі диверсифікації органічного виробництва 3 використанням місцевої сировини;

державне регулювання розвитку органічного виробництва, розроблення державних i регіональних програм його стимулювання (рис. 1).

3 метою досягнення Україною провідних позицій на світовому ринку органічних продуктів національним виробникам необхідно підвищувати свою конкурентоспроможність. Однак на сьогодні рівень конкуренції на внутрішньому ринку органічних продуктів ще недостатній. Натомість споживачами перевага надається дешевшим видам продукції, через що доволі часто імпортні продукти харчування посідають значну частку на українському ринку. Головною проблемою, яку необхідно вирішувати для збереження і розширення своїх позицій на ринках, залишається забезпечення зростання конкурентоспроможності продукції як за рахунок зниження витрат виробництва, так і на основі підвищення якості. На основі проведеного аналізу можна дійти висновку про те, впровадження науково обгрунтованих ресурсоощадних технологій на основі їх екологізації надасть можливість знизити витрати виробництва i поліпшити якість продукції, щуо своєю чергою дозволить підвищити конкурентоспроможність сільськогосподарських виробників та створить передумови для зниження рівня залежності національного ринку від імпорту.

В Україні поступово формується культура споживання органічних продуктів, а тому з'явився потенціал для розвитку цього сегмента продовольчого ринку. Однак необхідні зусилля для подолання сформованих підходів до організації виробництва i освоєння альтернативних технологій. Перехід суб'єктів господарювання до органічного виробництва потребує виконання ними низки вимог, для чого 
необхідною $є$ розробка науково обгрунтованої стратегії розвитку.

Розвиток виробництва органічної сільськогосподарської продукції відіграє важливу роль у системі ефективного використання земельно-ресурсного потенціалу та забезпечення зайнятості населення. У ряді країн виробництво органічної продукції розвивається уже понад сорок років, а сприяє цьому активна державна підтримка [11]. Натомість Україна перебуває на початковому етапі розвитку органічного сектора, а тому необхідно враховувати міжнародний досвід та формувати ефективний механізм розвитку виробництва органічної продукції. 3 цією метою доцільно запропонувати низку заходів й інструментів упливу, застосування яких сприятиме розвитку органічного виробництва в Україні.

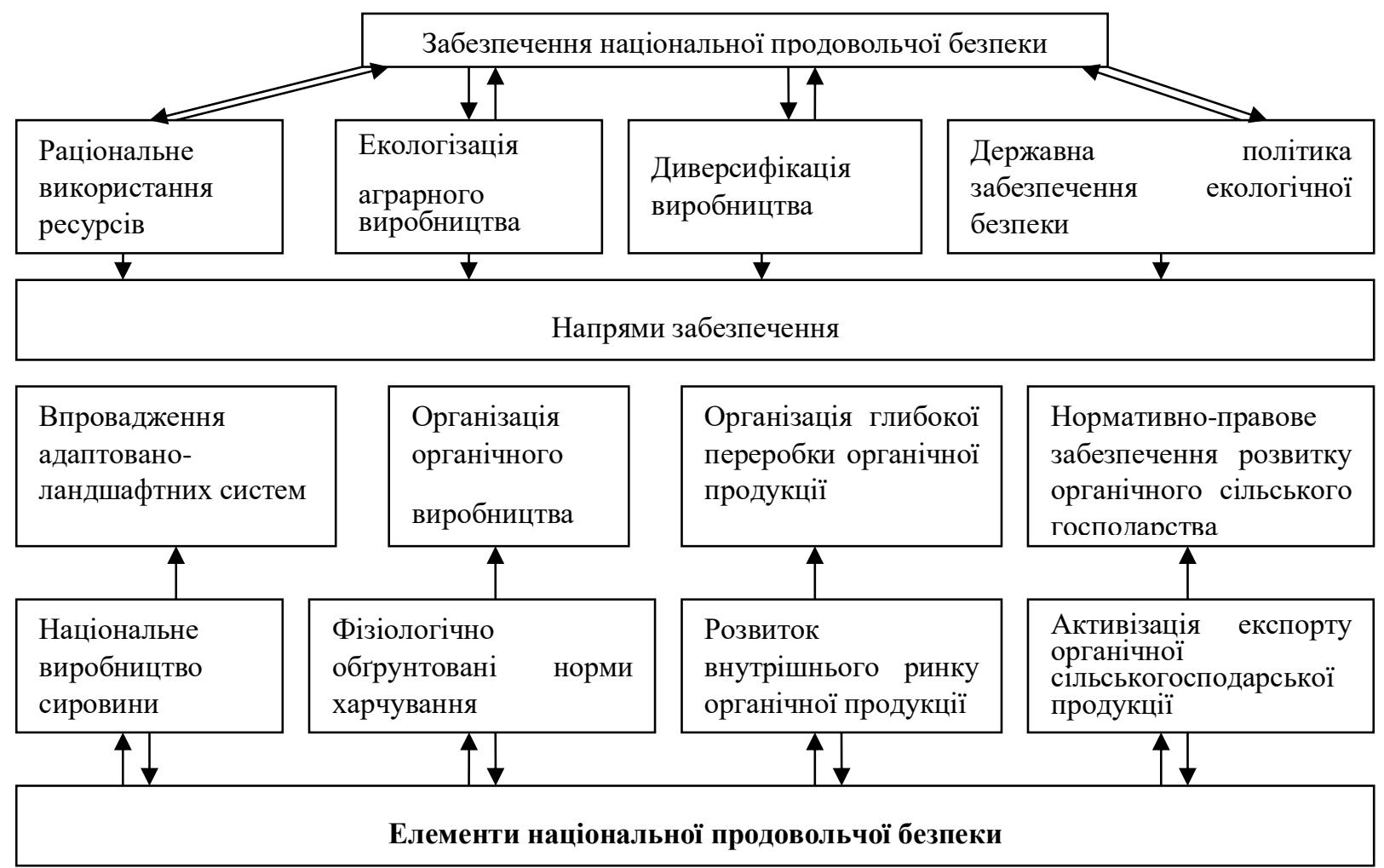

Рис. 1. Забезпечення продовольчої безпеки у контексті розвитку органічного виробництва Джерело: складено автором на основі [10; 11; 12]

Вирішення проблеми забезпечення країни основними продуктами харчування на основі національного виробництва потребує переходу від витратних технологій до ресурсоощадних, заснованих на екологізації. Україна має необхідні умови для розвитку органічного сільського господарства, а національні виробники повинні активно розвивати власні конкурентні переваги, що дасть змогу у найближчому майбутньому увійти їм до числа провідних експортерів органічної продукції [12].

Державна підтримка розвитку органічного сектора здійснюється перш за все на основі Закону України «Про виробництво та обіг органічної сільськогосподарської продукції та сировини» [13]. Однак поки не розроблено відповідних підзаконних актів, у зв'язку з чим національні виробники не є захищеними на ринку органічної продукції, а споживачі не завжди впевнені, що купують якраз органічну продукцію.
Це означає, що одним із вагомих чинників, який стримує розвиток органічного сектора України, $\epsilon$ недосконале інституційне забезпечення. В Україні розроблено приватні стандарти органічного сільськогосподарського виробництва та маркування сільськогосподарської продукції і продуктів харчування, що визнані Свропейською Комісією та $€$ першим українським сертифікаційним органом, який проводить сертифікацію органічного виробництва в Україні за стандартами $\mathrm{CC}$, а державні стандарти поки відсутні. Водночас відповідно до українського законодавства передбачається реалізація державного нагляду та контролю за дотриманням виробниками норм органічного виробництва.

У цьому зв'язку при вдосконаленні інституційного середовища органічного виробництва слід брати до уваги інтереси суб'єктів господарювання, рівень розвитку ринкової кон'юнктури, стан інфраструктури, 
правову підтримку суб'єктів господарювання, попит населення на продукти харчування, а промисловості - на органічну сировину, можливості відтворення природно-ресурсного потенціалу, дієвість функціонування системи моніторингу стану довкілля, рівень упровадження суб'єктами господарювання ресурсоощадних і безпечних технологій. Розвиток інституційного середовища органічного виробництва має сприяти створенню умов для формування системи сталого природокористування 3 урахуванням необхідності вдосконалення системи економічних відносин та підтримання соціального розвитку сільських територій.

Необхідно прискорити перехід від концептуальних засад аграрного природокористування до розроблення реального механізму розвитку конкурентоспроможного органічного сільського господарства. За своїм призначенням такий механізм повинен вирішувати ряд завдань, зокрема:
- д досягнення
стійкого
розвитку
природокористування у сфері сільськогосподарського виробництва на основі збалансованих i гармонійних відносин між соціальними чинниками, економічною діяльністю і довкіллям;

- підтримання задоволення економічних інтересів суб'єктів господарської діяльності;

- підвищення якості життя мешканців сільських територій та підтримання рівня зайнятості у сільській місцевості;

- розширення можливостей використання безпечних технологій на основі пріоритетів збереженню довкілля;

- зростання надходжень до місцевих бюджетів унаслідок підвищення економічної активності в аграрних регіонах та розширення експортних можливостей;

- забезпечення належних умов для обміну передовими технологіями $[15 ; 16]$.

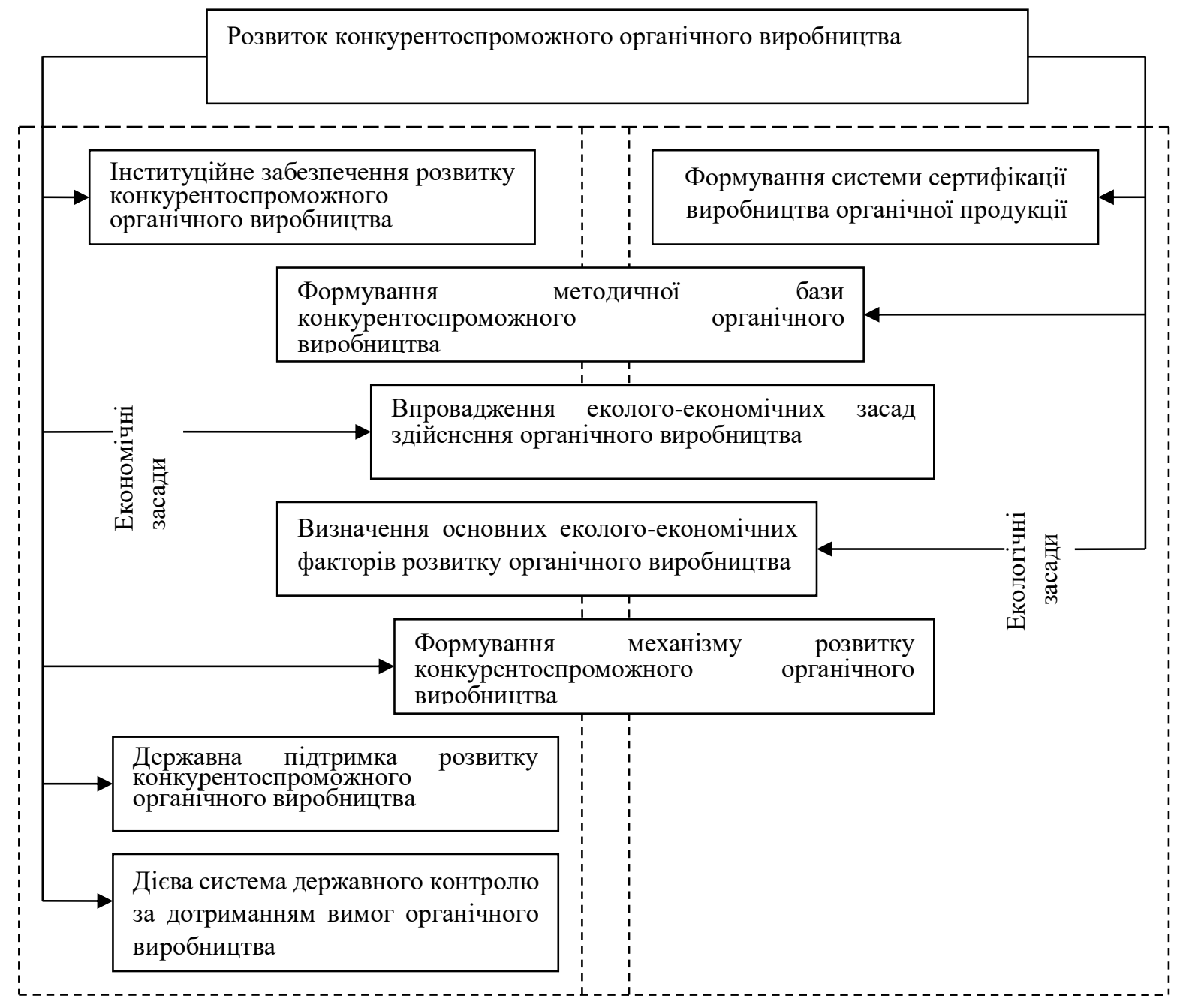

Рис. 2. Еколого-економічні засади розвитку конкурентоспроможного органічного виробництва

Джерело: складено автором на основі [4; 5; 6] 
Проведений аналіз дає змогу дійти висновку, що обмежений спектр дозволених засобів обробітку грунтів повинен стимулювати виробників, оскільки такий спосіб господарювання лише поліпшує якість грунтів. Дефіцит сировинної бази органічного походження $\epsilon$ цілком обгрунтованим через відсутність державного стимулювання, недостатньо розвинуту інфраструктуру, низьку екологічну свідомість і активність споживачів та виробників. Саме недостатня інноваційна активність сільськогосподарських підприємств, низький рівень екологічної свідомості та технологічної культури виробництва стримують розвиток ринку органічної продукції. Слід вказати й на складну демографічну ситуацію у сільській місцевості, загрозливі процеси депопуляції, погіршення вікової структури та низький рівень життя сільського населення порівняно з аналогічним показником у містах.

Істотним чинником, який стримує розвиток органічного виробництва, $є$ недостатній рівень професійних знань і досвіду у цій сфері господарювання через відсутність навчальних курсів 3 теорії і практики ведення органічного виробництва, брак дослідницьких господарств та недосконалу систему підготовки фермерів. Господарства, які використовують органічні методи виробництва, протягом кількох років мають удосконалювати якість виробництва та використовувати різні організації для поширення інформації і свого досвіду або можуть створювати власні дорадчі органи. Доцільно обрати у кожному регіоні декілька ферм, щзо стали б пілотними з органічного виробництва [17].

Розвиток інформаційного забезпечення розвитку ринків органічної продукції потребує підвищення рівня обізнаності суспільства, поширення інформації серед споживачів, впровадження прозорих стандартів ведення бізнесу, сприяння використанню торговельних марок (брендуванню) [18]. При цьому розвиток органічного виробництва спроможний генерувати додатковий капітал, заснований на використанні родючих земель, сільськогосподарських традицій, суспільної ментальності тощо [19]. Кожен зі вказаних факторів впливає на динаміку розвитку ринку органічної продукції. У систематизованому вигляді низка факторів впливу на розвиток виробництва органічної продукції наведена у табл. 1.

Таблиця 1

Фактори становлення і розвитку конкурентоспроможного органічного виробництва

\begin{tabular}{|c|c|}
\hline Групи факторів & Фактори \\
\hline \multirow[t]{5}{*}{ Організаційно-правові } & Інституційне підгрунтя \\
\hline & Національна система органічної сертифікації та стандартизації \\
\hline & Розвиток торговельно-збутової мережі \\
\hline & Інформаційне забезпечення \\
\hline & Екологічний аудит \\
\hline \multirow[t]{4}{*}{ Фінансово- економічні } & Система ціноутворення \\
\hline & Інвестування \\
\hline & Страхування \\
\hline & Система оподаткування та кредитування \\
\hline \multirow[t]{3}{*}{ Технологічні } & Дозволені засоби обробітку \\
\hline & Сировинна база органічного походження \\
\hline & Рівень поінформованості суб’єктів ринку \\
\hline \multirow[t]{5}{*}{ Соціально-психологічні } & Рівень екологічної свідомості населення \\
\hline & Інноваційна активність виробників \\
\hline & Демографічна ситуація \\
\hline & Рівень професійних знань \\
\hline & Маркування органічної продукції \\
\hline
\end{tabular}

Джерело: складено автором на основі: [4; 5; 6]

Важливе значення має формування позитивного сприйняття суб'єктами ринку необхідності виробляти та споживати екологічно безпечну продукцію. Значна частина споживачів демонструє прагнення купувати органічну продукцію, усвідомлюючи ії позитивне значення. Однак брак інформації щодо місць іiі продажу та обгрунтованості цін на неї, невміння ідентифікувати знаки маркування, невисокий рівень доходів багатьох категорій населення обмежує попит на органічну продукцію.

Слід вказати й на організаційно-правові фактори, які формуються 3 огляду на основі нормативно-правової бази. Для повноцінного 
функціонування органічного сільського господарства слід прийняти низку підзаконних актів та технічних регламентів. Однак аграрна політика в Україні перш за все спрямовується на підтримку зернотрейдерів та аграрних холдингів та спрямована перш за все на забезпечення інтенсивного виробництва зерна для експорту. Зрозуміло, що сучасний формат дії організаційноправових чинників має негативний вплив на функціонування органічного сільського господарства та стримує його розвиток. Аналіз фінансово-економічних чинників розвитку органічного сільського господарства дає змогу дійти висновку про те, що вони також не сприяють розвитку органічного виробництва в Україні.

Світовий досвід розвитку органічного виробництва свідчить про створення додаткових робочих місць $у$ сільській місцевості, появу нових перспектив для невеликих фермерських господарств, підвищення фінансової автономності сільських громад та інші соціальні переваги. У перспективі органічне сільське господарство дозволяє гармонізувати економічні, екологічні та соціальні цілі суспільного розвитку. Таким чином, стимулюючи розвиток органічного ринку, держава, 3 одного боку, отримує діючий інструмент задоволення актуальних потреб суспільства у безпечних товарах i засобах забезпечення екологічної безпеки, а $з$ іншого формує сектор економіки, здатний запропонувати нові робочі місця й залучити інвестиції.

Для створення системи формування га розвитку ринку органічної продукції необхідний системний підхід. Необхідно розглянути питання про вдосконалення державної політики стимулювання розвитку виробництва органічної сільськогосподарської продукції шляхом створення системи державного стимулювання, регулювання та контролю, оскільки без державної підтримки ведення органічного виробництва практично неможливе. Основними важелями економічного регулювання виробництва органічної продукції повинна стати бюджетна, податкова, цінова, кредитна, інвестиційна політика, державні замовлення, закупівельні і товарні інтервенції на ринку продовольства, заставні операції з виробленою підприємствами продукцією, лізингові операції, розробка цільових комплексних програм [18].

Необхідно врахувати й те, що потрібно виробити комплекс заходів, які сприятимуть збалансованості попиту й пропозиції органічної продукції на вітчизняному продовольчому ринку. Також необхідно проводити розумну протекціоністську політику, що забезпечує вітчизняним сільськогосподарським підприємствам умови для конкуренції на продовольчому ринку. 3 першочергових заходів необхідно виділити, зокрема, такі як:

- економічне стимулювання підприємств до виробництва органічної сільськогосподарської продукції за допомогою проведення податкової, митної, цінової, грошово-кредитної політики;

- установлення державного замовлення на виробництво органічної сільськогосподарської продукції;

- економічне регулювання імпорту органічних продуктів харчування та експорту сільськогосподарської сировини;

- створення умов для фінансування технічного переоснащення виробництва, у тому числі за рахунок зменшення оподатковуваної бази підприємств на величину власних коштів, спрямованих ними на технічне переоснащення;

- установлення податкових пільг для підприємств, що випускають органічну сільськогосподарську продукцію та вкладають свої кошти у впровадження нових інноваційних технологій, які сприяють випуску органічної продукції [19].

Серед напрямів стимулювання слід виділити формування механізму державної підтримки виробників органічної сільськогосподарської продукції (рис. 3). У зв'язку з цим необхідна мобілізація інвестиційних ресурсів суб'єктів господарювання для переходу від традиційного до органічного господарювання. За цих умов, як свідчить досвід країн з розвинутою економікою, держава має бути зацікавлена у позитивних екологічних зрушеннях, та покликана виробити ефективний механізм регулювання та визначити стратегічні пріоритети у сфері переходу до виробництва органічної продукції. При цьому головним напрямом здійснення державної політики має формування набору регуляторів та заходів для забезпечення сталого розвитку аграрного сектора економіки. Серед них основне місце посідають такі важелі, як кредити державних банків, податкові стимули, реалізація державно-приватного партнерствоа, іноземні інвестиції тощо. Таким чином, йдеться про стимулювання суб'єктів ринку до випуску органічної продукції. Держава повинна бути зацікавленою в ефективних виробниках органічної продукції та всіляко підтримувати їх подальший розвиток. Проте 3 метою стимулювання виробництва органічної продукції i розширення обсягу іii реалізації потрібне належне законодавче забезпечення, яке має регламентувати взаємини й відповідальність усіх учасників ринку. 
Концептуалізація розвитку органічного виробництва в Україні покликана забезпечити імплементацію інституційних основ виробництва i торгівлі (законодавчої бази; органічних стандартів; програм та спільних міжнародних проектів підтримки виробників, які включать в себе надання фінансової, технічної, консультативної допомоги); створення відповідного інфраструктурного забезпечення; вертикальної інтеграції; маркетингову концепцію розвитку.

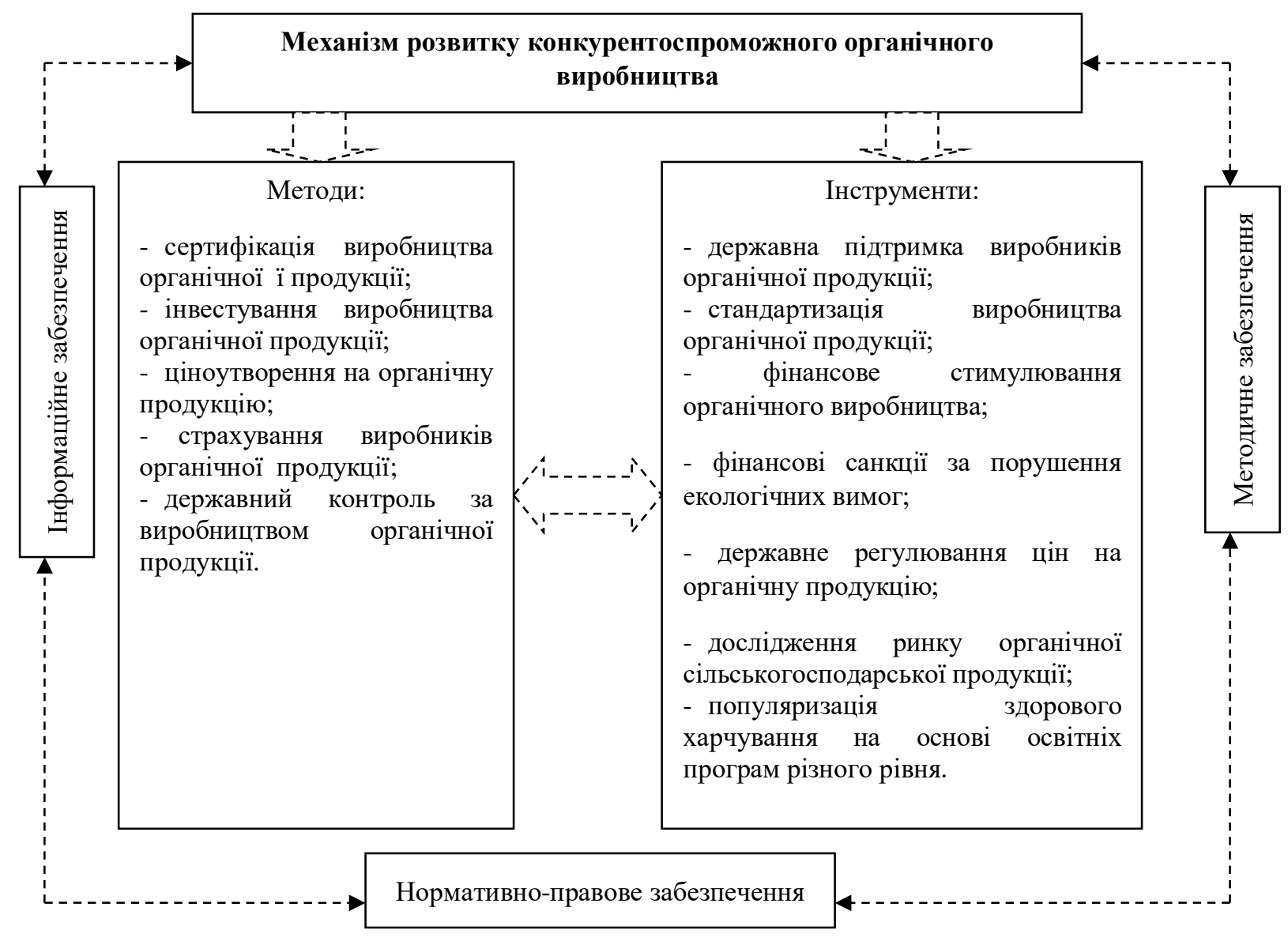

Рис. 3. Формування механізму розвитку конкурентоспроможного органічного виробництва

Джерело: складено автором на основі: [4; 5; 6]

Висновки та перспективи подальших дослджень. За сучасних умовах стратегічно важливим вектором розвитку національної економіки є органічне сільське господарство, що включає діяльність із виробництва, зберігання, переробки та реалізації органічної продукції відповідно до встановлених принципів та наявності нормативно-документів на ii здійснення. Комплексний вплив на зміни екологоекономічної системи суспільства здійснюють організаційно-економічні, екологічні, природнобіологічні, техніко-технологічні, соціальнокультурні та демографічні фактори. Такі чинники здійснюють свій вплив на основі глобальної конкуренції на світових ринках продовольчої продукції.

Таким чином, для розвитку конкурентоспроможного національного органічного виробництва потрібна послідовна державна політика, що має передбачати формування законодавчої бази, бюджетних пріоритетів, здійснення низки регуляторних заходів та організацію цивілізованого ринку органічної продукції. Саме 3 цією метою повинні бути сформовані передумови, серед яких нормативно-правове забезпечення, формування ринкових механізмів, державна підтримка виробників органічної сільськогосподарської продукції. При цьому ефективність державної підтримки може бути досягнута лише у разі комплексної реалізації державних і регіональних програм, спрямованих на розвиток національної системи сертифікації та стандартизації, поширення знань та інформації, консультативне забезпечення; наукові дослідження у секторі органічного виробництва. 


\section{ПЕРЕЛІК ВИКОРИСТАНИХ ДЖЕРЕЛ}

1. The Global Competitiveness Report 2019. Editor Klaus Schwab. http://www3.weforum.org/docs/WEF_TheGlobalCompetitivenessReport2019.pdf

2. Хвесик М. А., Бистряков І. К., Клиновий Д. В. Публічно-приватне партнерство в забезпеченні сталого просторового розвитку. Економіка України. 2020. №1. с. 3-23

3. Лагутін В. Д. Цивілізаційні та інституційні фактори глобальних економічних трансформацій XXI ст. Зовнішня торгівля: економіка, фінанси, право. 2019. №2. с. 5-19

4. Безус Р. М. Організаційно-економічні засади ефективного розвитку органічного агровиробництва. Дніпропетровськ: Лізунов Пресс, 2014. 380 с.

5. Завадська Ю. С. Ринок органічної агропродовольчої продукції: методологія становлення та розвитку. Житомир: Полісся, 2015. $216 \mathrm{c}$.

6. Патика Н. І. Конкурентоспроможність сільського господарства України: глобальний та національний вимір. Вінниця: Твори, 2019. 368 с.

7. Seegebarth B., Behrens S., Klarmann C., Hennigs N. Customer value perception of organic food: cultural differences and cross-national segments. British Food Journal. 2016. № 118. p. 396-411.

8. Кирилов Ю. Є., Грановська В. Г., Крикунова В. М. Чинники та стимули розвитку органічного сегмента аграрного виробництва в країнах світу. Економіка АПК. 2018. № 7. с. 16-27.

9. Кириленко І. Г., Милованов Є. В. Наукове забезпечення розвитку органічного агровиробництва. Економіка АПК. 2019. № 3. c. 27-41.

10. Ковальова О.В. Структурна політика та трансформації в аграрному секторі економіки. Київ: ННЦ IAE, 2019. $316 \mathrm{c}$.

11. Sauerborn J. Review of History and Recent Development of Organic Farming Worldwide. Agricultural Science in China. 2006. Vol. 5, №3. p. 169-178.

12. Lipper L., Thornton P., Campbell B. Climate-smart agriculture for food security. Nature Climate Change. 2014. № 4. p. 1068-1072.

13.Закон України «Про виробництво та обіг органічної сільськогосподарської продукції та сировини». Електронний ресурc. https://zakon.rada.gov.ua/laws/show/425-18

14. Brandt K., Leifert C., Sanderson R., Seal C. Agroecosystem. Management and nutritional quality of plant foods: the case of organic fruits and vegetables. Critical Reviews in Plant Sciences. 2011. № 30. p. 177-197.

15. Tuomisto H., Hodge I., Riordan P. Does organic farming reduce environmental impacts? A meta-analysis of European research. Journal of Environmental Management. 2012. № 112. p. 309-320.

16. Organic Market 2019. Triodos Bank. 2019. URL: https://www.soilassociation.org/media/17981/omr-report-2019interactive.pdf

17. Bullock G., Johnson C., Southwel B. Activating values to stimulate organic food purchases: can advertisements increase pro-environmental intentions? Journal of Consumer Marketing. 2017. № 34. p. 427-441.

18. Уманців Ю. М., Міняйло О. І. Економічна політика держави за умов глобальних трансформацій. Економіка України. 2018. № 9. с. 37-49

19. Овчаренко А. С. Маркетингові технології просування органічної агропродовольчої продукції на глобальному товарному ринку. Науковий вісник Ужгородського національного університету. Сер. Міжнародні економічні відносини та світове господарство. 2018. Вип. 18. ч. 2. с. 115-120

\section{REFERENCES}

1.The

http://www3.weforum.org/docs/WEF_TheGlobalCompetitivenessReport2019.pdf

2. Khvesyk, M.A., Bystryakov, I.K., Klynovyy D.V. (2020). Publichno-pryvatne partnerstvo v zabezpechenni staloho prostorovoho rozvytku [Public-private partnership in ensuring sustainable spatial development]. Ekonomika Ukrayiny. . №1. p. 3-23 [in Ukrainian]

3. Lahutin, V. (2019). Tsyvilizatsiyni ta instytutsiyni faktory hlobal'nykh ekonomichnykh transformatsiy XXI c. [Civilizational and institutional factors of global economic transformations of the XXI century]. Zovnishnya torhivlya: ekonomika, finansy, pravo. 2019. №2. p. 5-19 [in Ukrainian]

4. Bezus, R. M. (2014). Orhanizatsiyno-ekonomichni zasady efektyvnoho rozvytku orhanichnoho ahrovyrobnytstva. [Organizational and economic principles of effective development of organic agriculture]. Dnipropetrovs'k: Lizunov Press, 380 p. [in Ukrainian]

5. Zavads'ka, Y. S. (2015). Rynok orhanichnoyi ahroprodovol'choyi produktsiyi: metodolohiya stanovlennya ta rozvytku. [Market of organic agri-food products: methodology of formation and development]. Zhytomyr: Polissya, 216 p. [in Ukrainian]

6. Patyka, N. I. (2019). Konkurentospromozhnist' sil's'koho hospodarstva Ukrayiny: hlobal'nyy ta natsional'nyy vymir. [Competitiveness of agriculture of Ukraine: global and national dimension]. Vinnytsia, 368 p. [in Ukrainian]

7. Seegebarth, B., Behrens, S., Klarmann, C., Hennigs, N. (2016). Customer value perception of organic food: cultural differences and cross-national segments. British Food Journal. №118. p. 396-411. 
8. Kirilov, Y.E., Granovskaya, V.G., Krikunova, V.M. (2018). Chynnyky ta stymuly rozvytku orhanichnoho sehmenta ahrarnoho vyrobnytstva $\mathrm{v}$ krayinakh svitu [Factors and incentives for the development of the organic segment of agricultural production in the world]. Economics of agro-industrial complex. № 7. p. 16-27. [in Ukrainian]

9. Kirilenko, I.G., Milovanov, E.V. (2019). Naukove zabezpechennya rozvytku orhanichnoho ahrovyrobnytstva. [Scientific support for the development of organic agriculture. Economics of agro-industrial complex]. № 3. p. 27-41. [in Ukrainian]

10. Koval'ova, O.V. (2019). Strukturna polityka ta transformatsiyi v ahrarnomu sektori ekonomiky. [Structural policy and transformations in the agricultural sector of the economy]. 316 p. [in Ukrainian]

11. Sauerborn, J. (2006). Review of History and Recent Development of Organic Farming Worldwide. Agricultural Science in China. Vol. 5, №3. p. 169-178.

12. Lipper, L., Thornton, P., Campbell, B. (2014). Climate-smart agriculture for food security. Nature Climate Change. № 4. p. 1068-1072.

13. Law of Ukraine "On production and circulation of organic agricultural products and raw materials". https://zakon.rada.gov.ua/laws/show/425-18 [in Ukrainian]

14. Brandt, K., Leifert, C., Sanderson, R., Seal, C. (2011). Agroecosystem. Management and nutritional quality of plant foods: the case of organic fruits and vegetables. Critical Reviews in Plant Sciences. № 30. p. 177-197.

15. Tuomisto, H., Hodge, I., Riordan, P. (2012). Does organic farming reduce environmental impacts? A meta-analysis of European research. Journal of Environmental Management. №112. p. 309-320.

16. Organic Market 2019. Triodos Bank. 2019. URL: https://www.soilassociation.org/media/17981/omr-report-2019interactive.pdf

17. Bullock, G., Johnson, C., Southwel, B. (2017). Activating values to stimulate organic food purchases: can advertisements increase pro-environmental intentions? Journal of Consumer Marketing. № 34. p. 427-441.

18. Umantsiv, Iu. M., Minyailo, O. I. (2018). Ekonomichna polityka derzhavy za umov hlobal'nykh transformatsiy. Ekonomika Ukrayiny. [Economic policy of the state in the context of global transformations]. Ekonomika Ukrayiny. № 9. p. 37-49 [in Ukrainian]

19. Ovcharenko, A.S. (2018). Marketynhovi tekhnolohiyi prosuvannya orhanichnoyi ahroprodovol'choyi produktsiyi na hlobal'nomu tovarnomu rynku. [Marketing technologies for the promotion of organic agri-food products in the global commodity market]. Scientific Bulletin of Uzhhorod National University. S. International economic relations and the world economy. V. 18. Part 2. p. 115-120 [in Ukrainian]

Отримано 29.06.2020 